\title{
HUBUNGAN MOTIVASI DAN MORAL KERJA DENGAN PRESTASI KERJA PEGAWAI PADA SEKRETARIAT PEMERINTAH DAERAH KOTA BENGKULU
}

\author{
Sri Handayani ${ }^{1}$, Redo Yuhanda ${ }^{2}$ \\ ${ }^{1 \& 2}$ Universitas Dehasen Bengkulu \\ iiehandayani27@gmail.com ${ }^{1}$,vuhanda9@gmail.com ${ }^{2}$
}

\begin{abstract}
The aim of this study is to investigate the correlation between employees' motivation and work achievement and to find out the correlation between employees' work moral with their work achievement at the Secretariat of the Regional Government of Bengkulu City. The analytical method used is Spearman rank correlation and hypothesis testing. Based on rank spearman correlation analysis of the correlation between motivation and work performance of employees at the Secretariat of the Regional Government of Bengkulu City, it can be obtained that a value of 0.56 is in moderate criteria because the correlation results lie in the coefficient interval between $0.400-0.559$. From the hypothesis testing results, it can be stated that the correlation between motivation and employees' performance at the Secretariat of the Regional Government of Bengkulu City is 5.233 and it can be concluded that motivation (X1) has a significant correlation with employees' work performance at the Secretariat of the Regional Government of Bengkulu City because the $t$ value is greater than t table (1,67065). While rank spearman correlation analysis of the relationship between work moral towards work performance at the Secretariat of the Regional Government of Bengkulu City which obtained a value of 0.61 include as strong criteria because the correlation results lie in the coefficient interval between 0.600 - 0.799. From the results of hypothesis testing, the relationship between work morale and work performance of employees at the Secretariat of the Regional Government of Bengkulu City is 5.959 and it can be concluded that work moral (X2) has a significant correlation with work performance of employees at the Secretariat of the Regional Government of Bengkulu City because the $t$ value is greater than t table (1.67065).
\end{abstract}

Keywords: Motivation, Work Moral, Work Achievement

\section{PENDAHULUAN}

Sumber daya manusia merupakan satu-satunya sumber daya yang memiliki akal, perasaan, keinginan, kemampuan, keterampilan, pengetahuan dan dorongan. Semua potensi sumber daya manusia tersebut sangat berpengaruh terhadap upaya organisasi dalam pencapaian tujuannya. Betapapun majunya teknologi, berkembangnya informasi, tersedianya modal dan memadainya bahan, namun jika tanpa sumber daya manusia maka akan sulit bagi organisasi untuk mencapai tujuannya. Betapapun bagusnya perumusan tujuan dan rencana organisasi, hanya 
akan sia-sia belaka jika unsur sumber daya manusianya tidak diperhatikan, apalagi kalau di telantarkan.

Salah satu faktor pendukung terlaksananya pekerjaan yang baik adalah motivasi dari sumber daya manusia yang ada, sehingga keberhasilan suatu kegiatan dapat direalisasikan. Setiap kegiatan yang dilakukan oleh seseorang didorong oleh suatu kekuasaan dalam diri orang tersebut, kekuatan pendorong inilah yang disebut motivasi. Motivasi kerja pegawai merupakan kerelaan untuk mengarahkan upaya guna mencapai tujuan organisasi yang dipengaruhi oleh kemampuan usaha untuk memuaskan beberapa kebutuhan individu atau suatu proses psikologi yang berlangsung dalam interaksi antar kepribadian yang berbeda untuk memenuhi kebutuhan sebagai manusia.

Dengan adanya motivasi, seseorang pegawai akan merasa mempunyai dorongan khusus untuk menyelesaikan suatu pekerjaan menuju tercapainya prestasi kerja yang baik dalam organisasi. Ketika seorang pegawai memiliki motivasi untuk berprestasi, seseorang akan melaksanakan tugas dengan sebaik-baiknya, namun ketika orang menganggap bahwa melaksanakan pekerjaan hanya sebagai suatu rutinitas maka mereka cenderung statis dalam bekerja. Pimpinan harus memahami dan mengerti motivasi apa saja yang akan diberikan kepada para pegawai untuk memenuhi kebutuhannya agar para pegawai dapat bekerja dengan tenang dengan suasana kerja yang kondusif serta dapat memelihara dan meningkatkan motivasi pegawai dan kinerja instansi.

Setiap organisasi selalu berusaha agar prestasi kerja pegawai dapat ditingkatkan. Organisasi dalam bidang manapun pada hakekatnya merupakan sesuatu organik yang dinamis. Hal ini memberikan implikasi pada organisasi untuk bisa menselaraskan tujuan yang sudah ditetapkan sejalan dengan tujuan masingmasing individu. Untuk mewujudkan hal tersebut, perhatian utama pihak pimpinan adalah bagaimana mendayagunakan anggota organisasi untuk bekerja sesuai dengan tujuan yang ditetapkan. Untuk mewujudkan hal tersebut perlu disadari bahwa hasil kerja para pegawai tidak hanya bersumber dari kecakapan dalam mengerjakan tugas semata, akan tetapi dipengaruhi oleh faktor psikologisnya yaitu adanya semangat pada diri pegawai, yaitu moral kerja. Untuk itu pimpinan perlu mencari cara dan solusi guna menimbulkan moral kerja yang baik para karyawan. Hal itu penting, sebab moral kerja mencerminkan kesenangan yang mendalam terhadap pekerjaan yang dilakukan sehingga pekerjaan lebih cepat diselesaikan dan hasil yang lebih baik dapat dicapai.

Moral kerja adalah suatu predisposisi dari anggota organisasi untuk berupaya keras dalam mencapai sasaran dan tujuan organisasi. Moral meliputi komitmen terhadap tujuan. Moral adalah suatu fenomena kelompok yang meliputi upaya keras, adanya tujuan bersama dan perasaan memiliki dalam suatu organisasi (Gordon, 2010:754).

Pegawai akan bersedia bekerja dengan moral kerja yang baik apabila ia merasa bahwa kebutuhannya, baik fisik maupun non fisik terpenuhi melalui 
keterlibatannya dalam proses pencapaian tujuan pada organisasi yang bersangkutan. Moral kerja pegawai pada sebuah organisasi tergantung dari bagaimana perasaan pegawai terhadap pekerjaan yang dihadapinya saat ini, sehingga pegawai akan termotivasi untuk lebih bersemangat dalam melaksanakan pekerjaan dengan baik dan optimal.

Pegawai akan menunjukkan moral kerja yang sesuai dengan keinginan organisasi apabila pegawai tersebut dapat memiliki hubungan yang harmonis antara atasan dan bawahan, terdapat suasana dan iklim kerja yang bersahabat, rasa kemanfaatan bagi tercapainya tujuan organisasi, adanya tingkat kepuasan ekonomi dan kepuasan-kepuasan materi lainnya yang memadai, dan adanya ketenangan jiwa. Dengan mewujudkan hal tersebut maka pegawai dalam organisasi akan mampu memberikan prestasi kerja yang efektif dan sesuai dengan harapan organisasi.

Menurut Nasution (2009:33), tujuan atau harapan dari sebuah organisasi dalam menjalankan roda organisasinya adalah kualitas kerja, kuantitas kerja, disiplin kerja, inisiatif dan kerja sama yang baik yang dilakukan oleh pegawai dalam organisasi. Apabila faktor/indikator penting prestasi kerja tersebut dapat dicapai oleh seluruh pegawai dalam organisasi maka dapat dikatakan bahwa pegawai pada mampu mewujudkan harapan dan tujuan organisasi dengan maksimal dan organisasi akan mampu berjalan dengan baik.

Sekretariat Pemerintah Daerah Kota Bengkulu merupakan organisasi yang juga memerlukan pegawai yang mempunyai moral kerja yang bagus, dimana pegawai harus benar-benar mampu untuk menciptakan hubungan yang harmonis antara sesama pegawai termasuk antara bawahan dan atasan serta menciptakan iklim kerja yang bersahabat sehingga kepuasan kerja, prestasi kerja dapat tercapai. Akan tetapi saat ini masih dijumpai masih kurangnya motivasi kerja pegawai seperti kurangnya kesadaran dalam diri pegawai dalam melaksanakan tugas dan tanggung-jawabnya dalam bekerja, pegawai merasa belum mendapat perhatian yang sama dalam berbagai kegiatan, pegawai merasa belum mendapat kesempatan yang sama dalam mendapatkan jenjang karier yang lebih tinggi. Selain itu juga dalam hal moral kerja terlihat masih kurang harmonisnya hubungan antara karyawan yang disebabkan oleh karena kurangnya rasa kepercayaan dan keterbukaan terhadap sesama rekan kerja. Dan tentunya hal tersebut jika dibiarkan dapat memberikan dampak yang kurang baik terhadap kinerja pegawai.Berdasarkan latar belakang di atas penulis tertarik untuk melakukan penelitian dengan judul : Hubungan Motivasi dan Moral Kerja dengan Prestasi Kerja Pegawai pada Sekretariat Pemerintah Daerah Kota Bengkulu.

\section{TINJAUAN PUSTAKA}

\section{Motivasi Kerja}

Sifat dasar manusia bersumber dari adanya kebutuhan (needs) dan keinginan (want). Kebutuhan manusia meliputi segala hasrat manusia yang bersifat umum. Setiap manusia pada dasarnya membutuhkan sesuatu, walaupun prioritasnya berbeda-beda. Keinginan manusia meliputi hasrat manusia yang bersifat khusus, 
memiliki hubungan dengan suatu lingkup tertentu, baik lingkup ruang maupun waktu. Kebutuhan dan keinginan manusia inilah yang akan mempengaruhi perilaku seseorang.

Pentingnya motivasi karena motivasi adalah hal yang menyebabkan menyalurkan dan mendukung perilaku manusia, supaya mau bekerja giat dan antusias untuk mencapai hasil yang optimal. Motivasi semakin penting karena manajer membagikan pekerjaan kepada bawahannya untuk dikerjakan dengan baik dan terintegrasi tujuan yang diinginkan. Motivasi dirumuskan sebagai perilaku yang ditujukan pada sasaran. Motivasi berkaitan dengan tingkat usaha yang dilakukan oleh seseorang dalam mengejar suatu tujuan. Motivasi berkaitan erat dengan kepuasan pekerja dan performansi pekerjaan.

Istilah motivasi berasal dari kata latin movere yang berarti dorongan atau menggerakkan. Motivasi (motivation) dalam manajemen hanya ditujukan pada sumber daya manusia umumnya dan bawahan khususnya. Motivasi mempersoalkan bagaimana caranya mengarahkan daya dan potensi bawahan, agar mau bekerja sama secara produktif berhasil mencapai dan mewujudkan tujuan yang telah ditentukan (Hasibuan, 2011:141). Sedangkan menurut Mangkunegara (2011:61), motivasi terbentuk dari sikap (attitude) karyawan dalam menghadapi situasi kerja organisasi (situation). Motivasi merupakan kondisi atau energi yang menggerakkan diri karyawan yang terarah atau tertuju untuk mencapai tujuan organisasi sikap karyawan yang pro dan positif terhadap situasi kerja itulah yang memperkuat motivasi kerjanya untuk mencapai kinerja maksimal.

Handoko (2009:252), mengatakan bahwa pengertian motivasi adalah keadaan dalam pribadi seseorang yang mendorong keinginan individu untuk melakukan kegiatan-kegiatan tertentu guna mencapai tujuan, sedangkan Rivai (2010:457) mengatakan bahwa motivasi adalah suatu keahlian dalam mengarahkan karyawan dan perusahaan agar mau bekerja secara berhasil, sehingga keinginan karyawan dan tujuan perusahaan sekaligus tercapai.

Motivasi adalah pemberian daya penggerak yang menciptakan kegairahan kerja seseorang agar mereka mau bekerja sama, bekerja efektif dan terintegrasi dengan segala daya upayanya untuk mencapai kepuasan (Hasibuan, 2011:219). G. R. Terry dalam Hasibuan (2011:145), mengemukakan bahwa motivasi adalah keinginan yang terdapat pada diri seseorang individu yang merangsangnya untuk melakukan tindakan-tindakan. Kemudian Flippo dalam Hasibuan (2011:143), mengemukakan motivasi adalah suatu keahlian dalam mengarahkan pegawai dan organisasi agar mau bekerja sama secara berhasil, sehingga para pegawai dan tujuan organisasi sekaligus tercapai.

Martoyo (2010:16), menyatakan bahwa motivasi pada dasarnya adalah proses untuk mencoba mempengaruhi seseorang agar melakukan sesuatu yang kita inginkan. Lebih lanjut The Liang Gie dalam Martoyo (2010:165), memberikan perumusan motivasi sebagai pekerjaan yang dilakukan oleh seseorang manajer 
dalam memberikan inspirasi, semangat dan dorongan kepada orang lain, dalam hal ini karyawannya, untuk mengambil tindakan-tindakan. Pemberian dorongan ini bertujuan untuk menggiatkan orang-orang atau karyawan agar mereka bersemangat dan dapat mencapai hasil sebagaimana dikehendaki oleh orang-orang tersebut.

Dengan demikian dapatlah dikatakan bahwa motivasi pada dasarnya adalah kondisi mental yang mendorong dilakukannya suatu tindakan dan memberikan kekuatan yang mengarah kepada pencapaian kebutuhan, memberi kepuasan ataupun mengurangi ketidakseimbangan. Oleh karena itu tidak akan ada motivasi, jika tidak dirasakan adanya kebutuhan dan kepuasan serta ketidakseimbangan tersebut. Rangsangan-rangsangan terhadap hal semacam diataslah yang akan menumbuhkan motivasi dan motivasi yang telah tumbuh memang dapat menjadikan motor dan dorongan untuk mencapai tujuan pemenuhan kebutuhan atau pencapaian keseimbangan.

Tujuan pemberian motivasi itu antara lain sebagai berikut:

1. Meningkatkan moral dan kepuasan kerja karyawan.

2. Meningkatkan prestasi kerja/kinerja karyawan.

3. Mempertahankan kestabilan kerja karyawan.

4. Meningkatkan kedisiplinan.

5. Mengefektifkan pengadaan karyawan.

6. Menciptakan suasana dan hubungan kerja yang baik.

7. Meningkatkan loyalitas, kreativitas dan partisipasi karyawan.

8. Meningkatkan tingkat kesejahteraan karyawan.

9. Mempertinggi rasa tanggung jawab karyawan terhadap tugasnya tugasnya.

Hasibuan (2011:149), mengatakan bahwa metode motivasi adalah sebagai berikut:

a. Motivasi Langsung (Direct Motivation)

Motivasi langsung adalah motivasi (materiil dan Non Materiil) yang diberikan secara langsung kepada setiap individu karyawan untuk memenuhi kebutuhan serta kepuasannya, jadi sifatnya khusus, seperti pujian, penghargaan, tunjangan hari raya, bonus dan bintang jasa.

b. Motivasi Tidak Langsung (Indirect Motivation)

Motivasi Tidak langsung adalah motivasi yang diberikan hanya merupakan fasilitas-fasilitas yang mendukung serta menunjang gairah kerja atau kelancaran tugas sehingga para karyawan betah dan bersemangat melakukan pekerjaannya. Misalnya ruangan kerja yang nyaman, suasana pekerjaan yang serasi dan sejenisnya.

Beberapa teori motivasi yang dikenal dapat dikelompokkan atas:

\section{Teori Harapan (Expectancy)}

Teori harapan ini dikemukakan oleh Victor H. Vroom dalam Hasibuan (2011:165), menyatakan bahwa kekuatan yang memotivasi seseorang untuk bekerja giat dalam mengerjakan pekerjaannya tergantung dari hubungan timbal balik antara apa yang ia inginkan dan butuhkan dari hasil pekerjaan itu. Berapa besar ia yakin perusahaannya akan memberikan pemuasan bagi keinginannya 
sebagai imbalan atas usaha yang dilakukannya itu. Bila keyakinan yang diharapkan cukup besar untuk memperoleh kepuasannya maka ia akan bekerja keras pula dan sebaliknya.

Teori harapan itu didasarkan atas:

a. Harapan (Expectancy) adalah suatu kesempatan yang diberikan akan terjadi karena perilaku. Harapan nol menunjukkan bahwa tidak ada kemungkinan sesuatu hasil akan muncul sesudah prilaku atau tindakan tertentu dilakukan. Harapan ini dinyatakan dalam kemungkinan (Probabilitas).

b. Nilai (Valence) adalah akibat dari perilaku tertentu mempunyai nilai atau martabat tertentu (daya atau nilai motivasi) bagi setiap individu yang bersangkutan. Suatu hasil mempunyai valensi positif apabila disiplin dan lebih disegani, tetapi sebaliknya mempunyai valensi negatif jika tidak disiplin dan tidak disegani. Suatu hasil mempunyai nilai (valensi) nol, jika orang acuh tak acuh untuk mendapatkannya.

c. Pertautan (instrumentality) adalah persepsi dari individu bahwa hasil tingkat pertama akan dihubungkan dengan hasil tingkat kedua. Victor Vroom mengemukakan bahwa pertautan dapat mempunyai nilai yang berkisar nol dan minus satu. Hasil valensi minus satu (-1) menunjukkan persepsi bahwa tercapainya tingkat kedua adalah pasti tanpa hasil tingkat pertama. Dan tidak mungkin timbul dengan tercapainya hasil tingkat pertama $(+1)$ menunjukkan bahawa hasil tingkat pertama itu perlu dan sudah cukup untuk menimbulkan hasil tingkat kedua, karena hal ini menggambarkan suatu gabungan (asosiasi) maka instrumentality dapat dipikirkan sebagai pertautan (korelasi).

d. Motivasi adalah menilai besarnya dan arahnya semua kekuatan yang mempengaruhi perilaku individu. Tindakan yang didorong oleh kekuatan yang paling besar adalah tindakan yang paling mungkin dilakukan.

e. Ability (kemampuan) adalah menunjukkan potensi orang untuk melaksanakan pekerjaan. Kemampuan ini mungkin dimanfaatkan sepenuhnya atau mungkin juga tidak. Kemampuan ini berhubungan erat dengan daya pikir dan daya fisik yang dimiliki seseorang untuk melaksanakan pekerjaan.

\section{Teori Kepuasan}

Teori kepuasan mendasarkan pendekatannya atas faktor-faktor kebutuhan dan kepuasan individu yang menyebabkannya bertindak serta berperilaku dengan cara tertentu. Teori ini memusatkan perhatian pada faktor-faktor dalam diri orang yang menguatkan, mengarahkan, mendukung, dan menghentikan perilakuknya. Teori ini mencoba menjawab pertanyaan kebutuhan apa yang memuaskan seseorang dan apa yang mendorong semangat bekerja seseorang. Penganut teori motivasi kepuasan, antara lain Maslow dengan Maslow's Need Hierarchy Theory yang memperhatikan faktor-faktor manusia di tempat kerja dikenal dengan teori hirarki kebutuhan. Teori motivasi yang sangat terkenal adalah teori kebutuhan yang dikemukakan oleh Abraham Maslow. Hampir semua teori-teori motivasi berikutnya didasarkan pada teori hirarki kebutuhan Maslow. Walaupun setiap orang mempunyai kebutuhan, dorongan, aspirasi, dan kapabilitas spesifik, pada tingkat intensitas beragam, kebutuhan-kebutuhan dasar manusia adalah sama. 
Maslow dalam Martoyo (2010:159), menjelaskan Hirarki Kebutuhan yang diterapkan pada para pekerja secara garis besar sebagai berikut:

\section{a. Physiological Needs/kebutuhan fisik dan biologis}

Kebutuhan-kebutuhan dasar fisik yaitu kebutuhan untuk mempertahankan hidup. Yang termasuk ke dalam kebutuhan ini adalah kebutuhan makanan, minum, perumahan, udara dan kebutuhan-kebutuhan dasar lain untuk hidup. Kebutuhan-kebutuhan dasar fisik : kemampuan memperoleh makanan, perlindungan, pakaian dan kebutuhan-kebutuhan dasar lain untuk hidup.

b. Safety and Security Needs/kebutuhan keamanan dan keselamatan

Safety and Security Needs adalah kebutuhan akan kebebasan dari ancaman yakni merasa aman dari ancaman kecelakaan dan keselamatan dalam melaksanakan pekerjaan. Kebutuhan ini mengarah kepada dua bentuk yaitu pertama ; kebutuhan akan keamanan jiwa terutama keamanan jiwa di tempat pekerjaan seperti lingkungan kerja yang aman dan tidak ada ancaman, keselamatan kerja, kedua ; kebutuhan akan keamanan harta di tempat pekerjaan pada waktu jam-jam kerja, seperti peralatan dan instalasi-instalasi yang aman.

c. Affiliation or Acceptance needs/kebutuhan akan pengakuan Hubungan dan persahabatan dengan teman-teman sekerja, kebutuhan terhadap kelompok, aktivitas-aktivitas sosial dan kesempatan-kesempatan.

d. Esteem or Status Needs/kebutuhan akan pengakuan Kebutuhan akan pengakuan, penghargaan, reputasi, imbalan.

e. Self-Actualization/kebutuhan aktualisasi atau perwujudan diri

Merealisasikan suatu impian dan potensi, pencapaian tingginya hadiah dan talenta, kreativitas dan kepuasan kerja. Kebutuhan-kebutuhan ini bila dipenuhi maka para pekerja secara moral, emosional dan bahkan fisik siap untuk memuaskan kebutuhan-kebutuhan pengusaha dan para pelanggan.

\section{Teori Motivasi Proses}

Teori motivasi proses pada dasarnya berusaha menjawab pertanyaan bagaimana menguatkan, mengarahkan, memelihara dan menghentikan perilaku individu agar setiap individu bekerja sesuai keinginan manajer. Apabila diperhatikan teori ini merupakan proses sebab akibat dan bagaimana seseorang bekerja serta hasil apa yang akan diperolehnya. Jika bekerja baik saat ini, hasilnya akan diperoleh baik untuk hari esok. Jadi, hasil yang akan dicapai tercermin pada bagaimana proses kegiatan yang dilakukan seseorang.

2. Teori Pengukuhan

Teori ini didasarkan atas hubungan sebab dan akibat dari perilaku dengan pemberian kompensasi. Misalnya promosi tergantung dari prestasi yang selalu dapat dipertahankan.Orang mau bekerja untuk memenuhi kebutuhan dan kebutuhan harus dipenuhi dengan bekerja.

Menurut Peterson dan Plowman dalam Hasibuan (2011:142) menyatakan bahwa orang mau bekerja karena faktor-faktor berikut :

a. The desire to live (keinginan untuk hidup)

Keinginan untuk hidup merupakan keinginan utama dari setiap orang, manusia bekerja untuk makan dan minum untuk melanjutkan hidupnya. 
b. The desire for position (keinginan untuk suatu posisi)

Keinginan untuk suatu posisi dengan memiliki suatu keinginan manusia yang kedua dan salah satu sebab mengapa manusia mau bekerja.

c. The desire for power (keinginan akan kekuasaan)

Keinginan untuk suatu kekuasaan merupakan keinginan selangkah diatas keinginan untuk memiliki, mendorong orang mau bekerja.

d. The desire for recognation (keinginan akan pengakuan)

Keinginan akan pengakuan, penghormatan dan status sosial, merupakan jenis terakhir dari kebutuhan yang mendorong orang untuk bekerja. Dengan demikian setiap pekerja mempunyai motif keinginan (want) dan kebutuhan (needs) tertentu dan mengharapkan kepuasan dari hasil kerjanya.

Faktor-faktor motivasi kerja menurut Gomes (2012:180), motivasi orang bekerja melibatkan faktor-faktor sebagai berkut :

a. Faktor-faktor yang sifatnya individual adalah kebutuhan-kebutuhan atau (needs), tujuan-tujuan (goals), sikap (attitudes) dan kemampuan-kemampuan (abilities).

b. Faktor-yang berasal dari organisasi meliputi pembayaran atau gaji (pay), keamanan pekerjaan (job security), sesama pekerja (coworkes), pengawasan (supervision), pujian (praise) dan pekerjaan itu sendiri (job itself).

\section{Moral Kerja}

Moral kerja merupakan sikap yang ditunjukkan oleh pegawai dalam melaksanakan pekerjaan dalam sebuah organisasi. Menurut Gordon (2010:754), moral kerja adalah suatu predisposisi dari anggota organisasi untuk berupaya keras dalam mencapai sasaran dan tujuan organisasi. Moral meliputi komitmen terhadap tujuan itu. Moral adalah suatu fenomena kelompok yang meliputi upaya keras, adanya tujuan bersama dan perasaan memiliki.

Moral kerja memiliki pengertian yang sama dengan semangat kerja, Sastrohadiwiryo (2008:282) mengatakan moral kerja dapat diartikan sebagai suatu kondisi mental, atau perilaku individu tenaga kerja dan kelompok-kelompok yang menimbulkan kesenangan yang mendalam pada diri tenaga kerja untuk bekerja dengan giat dan konsekuen dalam mencapai tujuan yang telah ditetapkan perusahaan.Istilah moral digunakan untuk menerangkan perilaku organisasi. Di dalam organisasi bisnis, tentu saja pengertian moral tersebut dikaitkan dengan aktivitas kerja dan diistilahkan dengan employee morale.

Moral kerja merupakan terjemahan dari kata morale yang artinya moril atau semangat juang menurut Denyer dalam Moekijat (2011:136), kata semangat/moral (morale) itu mula-mula dipergunakan dalam kalangan militer untuk menunjukkan keadaan moral pasukan, akan tetapi sekarang mempunyai arti yang lebih luas dan dapat dirumuskan sebagai sikap bersama para pekerja terhadap satu sama lain, terhadap atasan, terhadap manajemen, atau pekerjaan.

Menurut Nitisemito (2010:160), moral kerja adalah melakukan pekerjaan secara lebih giat sehingga pekerjaan dapat diharapkan lebih cepat dan lebih baik. 
Sedangkan Hasibuan (2011:94) mengatakan semangat kerja sebagai keinginan dan kesungguhan seseorang mengerjakan pekerjaanya dengan baik serta berdisiplin untuk mencapai prestasi kerja yang maksimal. Dalam pendapat lain Siagian (2012:57) mengartikan bahwa moral kerja karyawan menunjukkan sejauh mana karyawan bergairah dalam melakukan tugas dan tanggung jawabnya di dalam perusahaan. Menurut beliau, moral kerja dapat dilihat dari kehadiran, kedisiplinan, ketepatan waktu, target kerja, gairah kerja serta tanggung jawab yang telah diberikan kepada karyawan tersebut.

Menurut Anwar (2012:180) adalah sebagai berikut : moral kerja merupakan suatu gambaran suatu perasaan agak berhubungan dengan tabiat/jiwa semangat kelompok, kegembiraan/ kegiatan, untuk kelompok-kelompok pekerja menunjukkan iklim dan suasana pekerja. Sedangkan Hasibuan (2011:94) mengemukakan bahwa moral kerja adalah keinginan dan kesungguhan seseorang mengerjakan pekerjaannya dengan baik serta berdisiplin untuk mencapai produktivitas yang maksimal.

Berdasarkan pengertian di atas maka dapat disimpulkan bahwa moral kerja merupakan sikap yang ditunjukkan karyawan berhubungan dengan tabiat/jiwa semangat kelompok, kegembiraan untuk kelompok-kelompok pekerja menunjukkan iklim dan suasana pekerja dilihat dari kehadiran, kedisiplinan, ketepatan waktu, target kerja, gairah kerja serta tanggung jawab yang telah diberikan kepada karyawan.

Banyak hal yang dapat mempengaruhi moral kerja seorang pegawai dalam sebuah organisasi adapun faktor-faktor yang mempengaruhi moral kerja menurut Danim (2009:212) adalah sebagai berikut:

1. Kesadaran akan tujuan organisasi.

Manusia yang sadar akan tujuan organisasinya biasanya memiliki tanggung jawab dan terdorong mencapai target kerja sesuai dengan tugas pokok dan fungsinya.

2. Hubungan antar manusia dalam organisasi berjalan harmonis.

Keharmonisan itu melahirkan susana atau iklim interaktif yang menyenangkan. Dengan adanya suasana yg menyenangkan itu gairah kerja seseorang secara otomatis akan terangsang.

3. Kepemimpinan yang menyenangkan.

Gaya kepemimpinan yang demokratis, jujur dan adil akan membangkitkan moral kerja karyawan karena mereka merasakan adanya pengakuan dan penghargaan.

4. Tingkatan organisasi.

Makin tinggi posisi manusia organisasional, pekerjaan yang dilakukannya akan semakin konseptual. Sebaliknya, semakin rendah posisi manusia dalan organisasi, pekerjaan yang dilakukannya makin tehnis. Dengan demikian, faktor-faktor yang mempengaruhi moral kerjanya akan berbeda pula.

5. Upah dan gaji. 
Secara umum, semakin tinggi upah dan gaji, makin tinggi pula moral kerja karyawan. Hal ini tidaklah mutlak karena pada unit kerja yang menawarkan upah dan gaji tinggi biasanya tuntutan kerjapun akan tinggi sehingga tak semua orang mampu melakukannya.

6. Kesempatan untuk meningkat atau promosi.

Manusia akan terdorong moral kerjanya manakala ada keyakinan bahwa dengan tampilan semacam itu akan terbuka akses baginya untuk meningkatkan karier atau promosi

7. Pembagian tugas dan tanggung jawab.

Kejelasan akan tugas dan tanggung jawab utama membuat manusia organisasional dapat bekerja dalam susana kepastian. Jika terjadi sebaliknya maka akan muncul keraguan. Karyawan yang bekerja dalam kebingungan kerja akan lebih banyak berfikir tidak produktif daripada bertindak secara riil.

8. Kemampuan individu.

Karyawan yang berbeda potensi, minat, intelegensi, kekuatan fisik, dsb, daya tanggapnya akan berbeda pula. Orang yang mempunyai daya tanggap tinggi, dengan signal sedikit saja moral kerjanya akan meningkat secara instan.

9. Perasaan diterima dalam kelompok.

Rasa diterima oleh anggota kelompok merupakan prasyarat bagi seseorang untuk dapat bekerja dengan derajat moral kerja tertentu.

10.Dinamika lingkungan.

Faktor lingkungan, baik lingkungan fisik maupun lingkungan non-fisik akan menentukan apakan seseorang terdorong untuk tampil dengan moral kerja yang tinggi ataukah sebaliknya.

11.Kepribadian.

Manusia dengan kepribadian terbuka, umumnya moral kerjanya mudah untuk dirangsang, sebaliknya manusia yang cenderung tertutup amat sulit untuk menerima rangsangan dan isyarat perubahan.

Jainudin dalam Mursani (2014:33) mengemukakan bahwa faktor-faktor yang dapat mempengaruhi moral kerja atau semangat kerja adalah :

1. Hubungan yang harmonis antara atasan dan bawahan

Terjalinnya hubungan yang harmonis terutama antara pimpinan kerja yang sehari-hari berhubungan dan berhadapan dengan para karyawan.

2. Terdapat suatu suasana dan iklim kerja yang bersahabat

Terdapat suatu suasana dan iklim kerja yang bersahabat dengan anggotaanggota lain organisasi, apalagi dengan mereka yang sehari-hari banyak berhubungan dengan pekerjaan.

3. Rasa kemanfaatan

Adaanya rasa kemanfaatan bagi tercapainya tujuan organisasi yang merupakan tujuan bersama mereka yang harus diwujudkan bersama-sama.

4. Adanya tingkat kepuasan ekonomi dan kepuasan-kepuasan materi lainnya yang memadai,

Adanya tingkat kepuasan ekonomi dan kepuasan-kepuasan materi lainnya yang memadai sehingga imbalan yang dirasakan akan adil terhadap jerih payah yang telah diberikan terhadap organisasi. 
5. Adanya ketenangan jiwa

Jaminan kepastian serta perlindungan terhadap segala yang dapat membahayakan diri pribadi dan karir pekerjaan dalam perusahaan atau organisasi menimbulkan rsa ketenangan jiwa pegawai.

\section{Prestasi Kerja}

Prestasi kerja menurut Mangkunegara (2011:67) adalah hasil kerja secara kualitas dan kuantitas yang dicapai oleh seseorang pegawai dalam melaksanakan tugasnya sesuai dengan tanggung jawab yang diberikan kepadanya. Hasibuan (2011:94) prestasi kerja adalah suatu hasil kerja yang dicapai seseorang dalam melaksanakan tugas-tugas yang dibebankan kepadanya atas kecakapan, pengalaman, dan kesungguhan serta waktu.Bernadin dan Russel dalam Sutrisno (2009:164) prestasi kerja adalah catatan tentang hasil-hasil yang diperoleh dari fungsi-fungsi pekerjaan tertentu atau kegiatan tertentu selama kurun waktu tertentu.

Dari beberapa pengertian diatas maka dapat disimpulkan bahwa prestasi kerja adalah kesuksesan atau hasil yang dicapai seseorang dalam melaksanakan pekerjaannya yang sesuai dengan tanggung jawab, kecakapan, pengalaman, keunggulan serta waktu yang diberikan perusahaan kepadanya dan harus dipertanggungjawabkan hasilnya kepada perusahaan.

Menurut Sutrisno (2009:164), prestasi kerja adalah hasil kerja yang telah dicapai seseorang dari tingkah laku kerjanya dalam melaksanakan aktivitas kerja. Informasi tentang tinggi rendahnya prestasi kerja seseorang karyawan tidak dapat diperoleh begitu saja, tetapi diperoleh melalui proses yang panjang, yaitu proses penilaian prestasi kerja karyawan yang disebut dengan istilah performance appraisal. Sedangkan menurut Hasibuan (2011:94) prestasi kerja adalah suatu hasil kerja yang dicapai seseorang dalam melaksanakan tugas-tugas yang dibebankan kepadanya yang didasarkan atas kecakapan, pengalaman dan kesungguhan serta waktu. Prestasi kerja merupakan gabungan dari tiga faktor penting yaitu kemampuan dan minat seorang pekerja.Semakin tinggi ketiga faktor di atas, semakin besarlah prestasi kerja karyawan bersangkutan.

Ada sejumlah tujuan yang biasanya dicapai oleh organisasi dengan menerapkan sebuah sistem manajemen prestasi kerja (Rivai, 2010:551) yaitu :

1) Meningkatkan prestasi kerja karyawan, baik secara individu maupun sebagai kelompok, sampai setinggi-tingginya dengan memberikan kesempatan pada mereka untuk memenuhi kebutuhan aktualisasi diri dalam kerangka pencapaian tujuan perusahaan. Karyawan bersama atasan masing-masing menetapkan sasaran kerja dan standar prestasi yang harus dicapai dan meneliti serta menilai hasil-hasil yang sebenarnya dicapai pada akhir kurun waktu yang ditetapkan.

2) Peningkatan yang terjadi pada prestasi karyawan secara perorangan pada gilirannya akan mendorong prestasi kerja sumberdaya manusia secara keseluruhan, yang direfleksikan dalam kenaikan produktivitas. 
3) Merangsang minat dan pengembangan pribadi dengan tujuan untuk meningkatkan hasil karya dan prestasi pribadi serta potensi laten karyawan dengan cara memberikan umpan balik pada mereka tentang prestasi mereka.

4) Membantu organisasi menyusun program pengembangan dan pelatihan karyawan yang lebih tepat guna. Pada gilirannya usaha ini akan membantu perusahaan untuk mempunyai pasokan tenaga yang cakap dan terampil yang cukup untuk pengembangan perusahaan di masa depan.

5) Menyediakan alat/sarana untuk membandingkan prestasi kerja pegawai dengan tingkat gajinya atau imbalannya sebagai bagian dari kebijakan dan sistim imbalan yang baik.

6) Memberikan kesempatan pegawai untuk mengeluarkan perasaannya tentang pekerjaan atau hal yang ada kaitannya. Dengan demikian jalur komunikasi dan dialog akan terbuka dan dengan demikian diharapkan bahwa proses penilaian prestasi kerja akan mengeratkan hubungan antara atasan dengan bawahan.

Dalam konsep prestasi kerja perlu memperhatikan asas/prinsip-prinsip manajemen antara lain (Hasibuan, 2011:10):

1) Adanya pembagian kerja yang jelas, maksudnya adanya spesialisasi akan meningkatkan efisiensi dalam pelaksanaan kerja adanya spesialisasi akan meningkatkan efisiensi dalam pelaksanaan kerja.

2) Adanya wewenang yang jelas, maksudnya adanya hak untuk memberi perintah dan dipatuhi.

3) Disiplin, maksudnya harus ada respek dan ketaatan pada peranan-peranan dan tujuan organisasi.

4) Adanya kesatuan perintah dan kesatuan pengarahan maksudnya karyawankaryawan hanya menerima intruksi dan pengarahan dari seorang atasan atau manajer sesuai bidang tugasnya, sehingga dalam pelaksanaannya jelas.

5) Melibatkan kepentingan perseorangan dibawah kepentingan umum maksudnya kepentingan perseorangan harus tunduk pada kepentingan organisasi.

6) Adanya balas jasa maksudnya adanya kompensasi pekerjaan yang dilaksanakan harus adil bagi semua karyawan.

7) Keadilan maksudnya harus ada kesamaan perilaku dalam organisasi.

8) Inisiatif maksudnya bawahan harus diberi kebebasan untuk menjalankan dan menyesuaikan rencananya walaupun beberapa kesalahan mungkin terjadi.

Penilaian prestasi kerja yang efektif akan memberikan dampak yang positif bagi pengelolaan kinerja karyawan dalam suatu organisasi. Dengan penilaian prestasi kerja yang efektif, organisasi dapat mengurangi konflik dalam pengelolaan kinerja.

Beberapa indikator penilaian prestasi kerja menurut Hasibuan (2009:95):

a. Kesetiaan

Kesetiaan dicerminkan oleh kesediaan karyawan menjaga dan membela organisasi didalam maupun diluar pekerjaannya.

b. Hasil Kerja 
Penilai menilai hasil kerja baik kualitas maupun kuantitas yang dapat dihasilkan oleh karyawan tersebut uraian pekerjaannya.

c. Kejujuran

Penilai menilai kejujuran dalam melaksanakan tugas-tugasnya memenuhi perjanjian baik bagi dirinya sendiri maupun terhadapa orang lain seperti kepada para bawahannya.

d. Kedisiplinan

Penilai menilai disiplin karyawan dalam mematuhi peraturan-peraturan yang ada dan mengajukan pekerjaannya sesuai dengan intsruksi yang diberikan kepadanya.

e. Kreativitas

Kemampuan karyawan dan mengembangkan kreativitas untuk menyelesaikan pekerjaanya, sehingga bekerja lebih berdaya guna

f. Kerjasama

Kesediaan karyawan berpartisipasi dan bekerja sama dengan karyawan lain, sehingga hasil pekerjaan akan lebih baik.

g. Kepemimpinan

Kemampuan untuk memimpin, mempengaruhi, mempunyai pribadi yang kuat, dihormati, beribawa dan dapat memotivasi orang lain atau bawahannya untuk bekerja secara efektif.

h. Kepribadian

Sikap, perilaku, kesopanan, disukai, memberikan kesan yang menyenangkan, memperhatikan sikap yang baik dan penampilan simpatik serta wajar dari karyawan tersebut.

i. Prakarsa

Kemampuan berfikir yang rasional dan berdasarkan inisiatif sendiri untuk menganalisa, menilai, menciptakan, memberikan alasan, mendapat kesimpulan dan membuat keputusan. Penyelesaian masalah yang dihadapinya.

j. Kecakapan

Kecakapan karyawan dalam menyatakan dan menjelaskan semua yang terlibat didalam penyusunan kebijakan perusahaan.

k. Tanggungjawab

Kejadian karyawan dalam mempertanggungjawabkan kebijaksanaan nya,pekerjaan dan hasil kerjanya, sarana dan prasarana yang digunakannya, perilaku serta hasil kerja dari bawahannya

Menurut Mangkunegara (2011:67) hal yang perlu diperhatikan oleh manajer sumber daya manusia dalam prestasi kerja pegawai, indikatornya meliputi :

1. Kualitas kerja

Kualitas kerja menunjukkan hasil kerja yang dicapai dari segi ketepatan, ketelitian dan keterampilan.

2. Kuantitas kerja

Kuantitas kerja menunjukkan hasil kerja yang dicapai dari segi keluaran atau hasil tugas-tugas rutinitas dan kecepatan dalam menyelesaikan tugas itu sendiri.

3. Kerja sama 
Kerja sama menyatakan kemampuan karyawan dalam berpartisipasi dan bekerjasama dengan orang lain dalam menyelesaikan tugas.

4. Tanggung Jawab

Tanggung Jawab menyatakan seberapa besar karyawan dalam menerima dan melaksanakan pekerjaannya.

5. Inisiatif

Inisiatif yakni bersemangat dalam menyelesaikan tugasnya, serta kemampuan dalam membuat suatu keputusan yang baik tanpa adanya pengarahan terlebih dahulu.

\section{METODE PENELITIAN}

Metode yang digunakan dalam penelitian ini adalah :

Korelasi Rank Spearman

Korelasi Rank Spearman merupakan korelasi yang digunakan untuk mencari hubungan atau pengujian signifikasi hipotesis asosiatif, jika variabel memiliki bentuk data ordinal, dan sumber data belum tentu sama (Sugiyono, 2011:356). Adapun rumus dari korelasi Spearman Rank sebagai berikut :

$$
\begin{aligned}
\rho & =1-\frac{6 \sum b_{i}^{2}}{n\left(n^{2}-1\right)} \\
\rho & =\text { Koefisien korelasi Spearman Rank } \\
b_{i}{ }^{2} & =\text { Perbedaan setiap pasang rank } \\
\mathrm{n} & =\text { Jumlah pasang rank }
\end{aligned}
$$

Untuk mengetahui hubungan antara motivasi dan moral kerja dengan prestasi kerja pegawai pada Sekretariat Pemerintah Daerah Kota Bengkulu digunakan interpretasi korelasi (Sugiyono, 2011:358) sebagai berikut :

Tabel 3

Interval korelasi

\begin{tabular}{|c|c|}
\hline ll korelasi & Keterangan \\
\hline$-0,199$ & Sangat rendah \\
\hline$-0,399$ & Rendah \\
\hline$-0,599$ & Sedang \\
\hline$-0,799$ & Kuat \\
\hline$-1,000$ & Sangat Kuat \\
\hline
\end{tabular}

Sumber : Sugiyono, 2011:133.

\section{Uji Hipotesis}

Untuk menentukan diterima atau ditolaknya hipotesis yang diajukan dalam penelitian ini maka dilakukan pengujian hipotesis dengan menggunakan uji-t (Sugiyono, 2011:116) sebagai berikut : 


$$
\begin{aligned}
& \mathrm{t}_{\text {hitung }}=\mathrm{rs} \sqrt{\frac{n-2}{1-r s^{2}}} \\
& \mathrm{n}=\text { jumlah sampel } \\
& \mathrm{rs}=\text { nilai korelasi Spearman Rank. } \\
& \mathrm{t}=\text { Nilai uji } \mathrm{t}
\end{aligned}
$$

Penentuan tingkat keyakinan/level of significantnya adalah $95 \%$ dengan tingkat penyimpangan atau $\alpha=0,05$.

Kriteria pengujian hipotesisnya adalah :

1) Penentuan level of significant $95 \%$ atau alpha $(\alpha) 5 \%$

2) Membandingkan nilai thitung dengan $t$ tabel dengan ketentuan:

a. Ho ditolak dan Ha diterima jika thitung lebih besar dari t tabel artinya terdapat hubungan signifikan antara motivasi dan moral kerja dengan prestasi kerja pegawai pada Sekretariat Pemerintah Daerah Kota Bengkulu.

b. Ho diterima dan Ha ditolak jika t hitung lebih kecil dari t tabel maka artinya tidak terdapat hubungan signifikan antara motivasi dan moral kerja dengan prestasi kerja pegawai pada Sekretariat Pemerintah Daerah Kota Bengkulu.

\section{Hipotesis}

Hipotesis penelitian ini adalah :

1. Diduga motivasi kerja mempunyai hubungan signifikan dengan prestasi kerja pegawai pada Sekretariat Pemerintah Daerah Kota Bengkulu.

2. Diduga moral kerja mempunyai hubungan signifikan dengan prestasi kerja pegawai pada Sekretariat Pemerintah Daerah Kota Bengkulu.

\section{HASIL PENELITIAN DAN PEMBAHASAN}

Berdasarkan hasil perhitungan korelasi rank spearman dan pengujian hipotesis diperoleh hasil sebagaimana pada tabel berikut ini :

Tabel 7. Rekap Hasil Penelitian dengan Perhitungan Korelasi dan Uji Hipotesis antara X1 denganY

\begin{tabular}{|l|l|l|l|l|l|}
\hline Variabel & $\begin{array}{l}\text { Korelasi } \\
\text { Rank } \\
\text { Spearman } \\
(\rho)\end{array}$ & Kriteria & $\begin{array}{r}\mathrm{t} \\
\text { hitung }\end{array}$ & $\begin{array}{r}\mathrm{t} \\
\text { tabel }\end{array}$ & Kriteria \\
\hline $\begin{array}{l}\text { asi (X1) dan } \\
\text { prestasi kerja (Y) }\end{array}$ & & sedang & 5,233 & 1,67065 & Signifikan \\
\hline
\end{tabular}

Sumber : Hasil Penelitian, Diolah, 2019

Dalam analisis korelasi rank spearman terhadap motivasi dengan prestasi kerja pegawai pada Sekretariat Pemerintah Daerah Kota Bengkulu diperoleh nilai 0,56 kriteria sedang karena hasil korelasinya terletak pada interval koefisien antara $0,400-0,599$. Dari hasil uji hipotesis hubungan antara motivasi dengan prestasi kerja pegawai pada Sekretariat Pemerintah Daerah Kota Bengkulu adalah 5,233 sehingga dapat disimpulkan bahwa motivasi (X1) mempunyai hubungan 
signifikan dengan prestasi kerja pegawai pada Sekretariat Pemerintah Daerah Kota Bengkulu karena nilai t hitung lebih besar dari t tabel $(1,67065)$.

Tabel 8. Rekap Hasil Penelitian dengan Perhitungan Korelasi dan Uji Hipotesis antara X2 denganY

\begin{tabular}{|c|l|l|c|c|c|}
\hline Variabel & $\begin{array}{l}\text { Korelasi } \\
\text { Rank } \\
\text { Spearman } \\
(\rho)\end{array}$ & Kriteria & $\begin{array}{c}\mathrm{t} \\
\text { hitung }\end{array}$ & $\mathrm{t}$ tabel & Kriteria \\
\hline $\begin{array}{l}\text { Moral kerja } \\
\text { (X2) dan } \\
\text { prestasi kerja } \\
(\text { Y) }\end{array}$ & 0,61 & kuat & 5,959 & 1,67065 & Signifikan \\
\hline
\end{tabular}

Sumber : Hasil Penelitian, Diolah, 2019

Dalam analisis korelasi rank spearman terhadap hubungan moral kerja dengan prestasi kerja pegawai pada Sekretariat Pemerintah Daerah Kota Bengkulu diperoleh nilai 0,61 kriteria kuat karena hasil korelasinya terletak pada interval koefisien antara 0,600 - 0,799. Dari hasil uji hipotesis hubungan antara moral kerja dengan prestasi kerja pegawai pada Sekretariat Pemerintah Daerah Kota Bengkulu adalah 5,959 sehingga dapat disimpulkan bahwa moral kerja (X2) mempunyai hubungan signifikan dengan prestasi kerja pegawai pada Sekretariat Pemerintah Daerah Kota Bengkulu karena nilai t hitung lebih besar dari t tabel $(1,67065)$.

Sekretariat Pemerintah Daerah Kota Bengkulu merupakan sebuah organisasi milik pemerintah Bengkulu yang bertugas membantu kepala daerah dalam menyusun kebijakan dan mengkoordinasikan dinas daerah dan lembaga teknis daerah. Dalam pelaksanaan tugas dan kewajibannya, sekretaris daerah bertanggung jawab kepada Kepala Daerah dalam hal ini adalah Walikota. Beban pekerjaan seluruh pegawai pada Sekretariat Pemerintah Daerah Kota Bengkulu membuat Sekretariat Pemerintah Daerah Kota Bengkulu harus mampu mengetahui apa saja yang bisa memotivasi pegawai mampu memberikan prestasi kerja yang sesuai dengan harapan Sekretariat Pemerintah Daerah Kota Bengkulu. Dalam memberikan motivasi kepada pegawai Sekretariat Pemerintah Daerah Kota Bengkulu, maka Sekretariat Pemerintah Daerah Kota Bengkulu melakukan beberapa hal yang diantaranya adalah memenuhi beberapa kebutuhan yang dapat memicu pegawai untuk lebih semangat dalam melaksanakan pekerjaannya. Dalam pemenuhan kebutuhan psikologis seperti pemenuhan kebutuhan makan, serta tempat tinggal yang dirasa sudah mampu pegawai penuhi dengan bekerja pada Sekretariat Pemerintah Daerah Kota Bengkulu.

Pegawai Sekretariat Pemerintah Daerah Kota Bengkulu juga difasilitasi dengan pemenuhan kebutuhan keamanan dengan dilakukannya penjaminan kerugian yang kemungkinan akan dialami oleh pegawai ketika melaksanakan pekerjaan dengan 
memberikan asuransi, serta memberikan fasilitas alat kerja yang dianggap tidak membahayakan jiwa pegawai yang melaksanakan pekerjaan.

Pegawai Sekretariat Pemerintah Daerah Kota Bengkulu pegawai merasa mendapatkan perhatian yang sama dalam berbagai acara, dan bukan hanya itu saja kesetaraan tersebut juga menimbulkan hubungan yang positif oleh seluruh pegawai Sekretariat Pemerintah Daerah Kota Bengkulu yang bekerja.

Pegawai mengakui bahwa kebutuhan akan pengakuan juga akan sangat membantu pegawai untuk merasa puas dan pada akhirnya melaksanakan pekerjaan dengan lebih baik lagi, maka dari itu Sekretariat Pemerintah Daerah Kota Bengkulu memberikan kesempatan yang sama dalam mendapatkan jenjang karir yang lebih tinggi, serta mengakui hasil kerja pegawai. Dalam bekerja maka hal yang harus dilakukan oleh pegawai Sekretariat Pemerintah Daerah Kota Bengkulu agar dapat mencapai prestasi kerja yang maksimal maka pegawai harus yakin akan kemampuannya sehingga Sekretariat Pemerintah Daerah Kota Bengkulu selalu mendorong pegawai untuk selalu sadar bahwa masing-masing pegawai memiliki kemampuan dan setiap prestasi kerja yang baik membutuhkan kerja keras pula.

Selain motivasi yang tinggi maka pegawai dengan prestasi kerja yang tinggi juga harus memiliki moral kerja yang positif, karena dengan demikian maka dorongan untuk melakukan pekerjaan secara maksimal akan semakin besar dan hal ini akan berdampak pada pencapaian kerja yang baik yang sesuai dengan apa yang diharapkan oleh Sekretariat Pemerintah Daerah Kota Bengkulu.

Sekretariat Pemerintah Daerah Kota Bengkulu diketahui telah memiliki pegawai dengan moralitas yang tinggi terhadap pekerjaannya, dimana hal ini dapat dilihat dari adanya hubungan yang harmonis terhadap sesama pegawai dan antara pegawai dengan pimpinan, dan hal ini mendorong pegawai selalu bersedia untuk saling membantu dalam penyelesaian pekerjaan.

Dari hubungan yang harmonis tersebut maka pegawai pada Sekretariat Pemerintah Daerah Kota Bengkulu dapat menciptakan suasana dan iklim kerja yang bersahabat dengan diciptakannya suasana kerja yang kondusif dan menyenangkan, suasana kerja yang kondusif dan menyenangkan akan menstimulasi perasaan pegawai untuk bersedia melakukan pekerjaan dengan nyaman dan tidak merasa tertekan dan dampak dari hal tersebut akan dapat menguntungkan pegawai maupun Sekretariat Pemerintah Daerah Kota Bengkulu.

Pegawai Sekretariat Pemerintah Daerah Kota Bengkulu merasakan bahwa melakukan pekerjaan merupakan hal yang harus dilakukan mengingat pegawai harus memenuhi kebutuhan yang diperoleh dari hasil timbal balik yang diberikan oleh pemerintah kepada pegawai Sekretariat Pemerintah Daerah Kota Bengkulu, maka dari itu Sekretariat Pemerintah Daerah Kota Bengkulu menciptakan kepuasan pada diri pegawai yang bekerja baik. 
Berbagai hal positif yang dirasakan oleh pegawai ketika melaksanakan pekerjaan pada Sekretariat Pemerintah Daerah Kota Bengkulu membuat pegawai pada Sekretariat Pemerintah Daerah Kota Bengkulu merasa bahwa Sekretariat Pemerintah Daerah Kota Bengkulu telah memberikan ketenangan jiwa, karena terhindar dari stres kerja yang mengakibatkan prestasi kerja menurun, dan sebaliknya pegawai Sekretariat Pemerintah Daerah Kota Bengkulu merasa bahwa prestasi kerja yang di tuntut oleh Sekretariat Pemerintah Daerah Kota Bengkulu dapat dicapai oleh pegawai dengan maksimal dan pegawai bersedia untuk selalu bekerja dan terus berupaya untuk meningkatkan prestasi kerjanya.

Prestasi kerja yang baik yang dapat dilihat dari hasil penelitian yang dilakukan dapat dilihat dari kualitas kerja yang dihasilkan oleh pegawai pada Sekretariat Pemerintah Daerah Kota Bengkulu, dimana pegawai dirasa melaksanakan pekerjaan dengan baik dan terus berupaya untuk meningkatkan kualitas kerjanya tersebut.

Bukan hanya dari segi kualitas saja akan tetapi pegawai pada Sekretariat Pemerintah Daerah Kota Bengkulu dirasa telah memberikan kuantitas yang maksimal dimana pegawai mampu melaksanakan pekerjaan yang diperintahkan sesuai dengan biaya, dan waktu yang telah ditetapkan oleh Sekretariat Pemerintah Daerah Kota Bengkulu sehingga pegawai dianggap tidak merugikan Sekretariat Pemerintah Daerah Kota Bengkulu.

Prestasi kerja pegawai bukan hanya dilihat dari kuantitas kerja maupun kualitas kerja yang dihasilkan, prestasi kerja pegawai Sekretariat Pemerintah Daerah Kota Bengkulu juga dapat dilihat dari adanya kemauan pegawai Sekretariat Pemerintah Daerah Kota Bengkulu untuk melaksanakan pekerjaan yang diberikan, hal ini dapat dilihat dari pegawai cepat dan tanggap terhadap perintah yang diinstruksikan dan pelaksanaan pekerjaan yang dilakukan secara bersama-sama.

Diketahui bahwa Sekretariat Pemerintah Daerah Kota Bengkulu memiliki pegawai yang memiliki komitmen tinggi dalam dedikasinya bekerja, dimana pegawai selalu mengerjakan pekerjaan tanpa menunda-nundanya, bukan hanya itu saja pegawai Sekretariat Pemerintah Daerah Kota Bengkulu juga didorong oleh inisiatif yang tinggi sehingga pekerjaan tidak menumpuk dan pemimpin terbantu karena pegawai sudah memahami apa yang harus dikerjakan tanpa harus diberikan perintah secara khusus.

\section{KESIMPULAN DAN SARAN \\ Kesimpulan}

Berdasarkan dari hasil penelitian mengenai hubungan motivasi dan moral kerja dengan prestasi kerja pegawai pada Sekretariat Pemerintah Daerah Kota Bengkulu maka dapat ditarik suatu kesimpulan yaitu :

1. Berdasarkan analisis korelasi rank spearman terhadap hubungan motivasi dengan prestasi kerja pegawai pada Sekretariat Pemerintah Daerah Kota Bengkulu diperoleh nilai 0,56 kriteria sedang karena hasil korelasinya terletak 
pada interval koefisien antara 0,400 - 0,559. Dari hasil uji hipotesis hubungan antara motivasi dengan prestasi kerja pegawai pada Sekretariat Pemerintah Daerah Kota Bengkulu adalah 5,233 dan dapat disimpulkan bahwa motivasi (X1) mempunyai hubungan signifikan dengan prestasi kerja pegawai pada Sekretariat Pemerintah Daerah Kota Bengkulu karena nilai t hitung lebih besar dari t tabel (1,67065).

2. Berdasarkan analisis korelasi rank spearman terhadap hubungan moral kerja dengan prestasi kerja pada Sekretariat Pemerintah Daerah Kota Bengkulu diperoleh nilai 0,61 kriteria kuat karena hasil korelasinya terletak pada interval koefisien antara 0,600 - 0,799. Dari hasil uji hipotesis hubungan antara moral kerja dengan prestasi kerja pegawai pada Sekretariat Pemerintah Daerah Kota Bengkulu adalah 5,959 dan dapat disimpulkan bahwa moral kerja (X2) mempunyai hubungan signifikan dengan prestasi kerja pegawai pada Sekretariat Pemerintah Daerah Kota Bengkulu karena nilai t hitung lebih besar dari t tabel $(1,67065)$.

\section{Saran}

Diharapkan bahwa Sekretariat Pemerintah Daerah Kota Bengkulu dapat memberikan pegawai yang memiliki prestasi untuk memperoleh kesempatan dalam berkarier, sehingga pegawai merasa diakui dan dihargai yang selanjutnya akan meningkatkan motivasi kerja pegawai. Selain itu agar moral kerja dan prestasi kerja pegawai Sekretariat Pemerintah Daerah Kota Bengkulu dapat ditingkatkan maka pimpinan harus meningkatkan suatu keadaan dimana terjalin hubungan yang harmonis antara pegawai dan antara pimpinan dengan bawahan, perlu diciptakan suasana dan iklim kerja yang baik dan bersahabat dengan sesama pegawai lainnya, menciptakan ketenangan jiwa pegawai dalam bekerja serta meningkatkan tingkat kepuasan ekonomi pegawai dengan baik sehingga prestasi kerja pegawai akan lebih baik.

\section{DAFTAR PUSTAKA}

Arikunto, Suharsimi. 2012. Manajemen Penelitian. Jakarta : Rineka Cipta

Anwar. 2012. Manajemen Sumber Daya Manusia Perusahaan. Bandung : Remaja Rosdakarya

Danim, Sudarwan. 2009. Motivasi Kepemimpinan dan Efektivitas Kelompok. Jakarta : Penerbit Rineka Cipta

Gordon, Judith R. A. 2010. Diagnostic Approach to Organizational Behaviour. Boston : Allyn \& Bacon

Gomes, Faustino Cardoso. 2012. Manajemen Sumber Daya Manusia Yogyakarta: Andi 
Hasibuan, S.P, Malayu. 2011. Manajemen Sumber Daya Manusia, Jakarta : Bumi Aksara

Handoko, Hani. 2009. Manajemen Personalia dan Sumber Daya Manusia. Yogyakarta: BPFE

Martoyo, Susilo. 2010. Manajemen Sumber Daya Manusia. Yogyakarta: BPFE

Mangkunegara, Anwar Prabu 2011. Manajemen Sumber Daya Manusia Perusahaan. Bandung : PT Remaja Rosdakarya

Moekijat. 2011. Fungsi-Fungsi Manajemen. Bandung : CV. Mandar Maju.

Mursani, Ahmad. 2014. Korelasi antara Kepemimpinan dan Semangat Kerja Pegawai di Dinas Kesejahteraan Sosial Kota Samarinda. E-Journal Ilmu Pemerintahan. ISSN. 2338-3651. Universitas Mulawarman:Samarinda

Nasution. 2009. Metode Research: Penelitian Ilmiah. Jakarta: Bumi Aksara

Nitisemito, Alex S. 2010. Manajemen Personalia : Manajemen Sumber Daya Manusia. Jakarta : Ghalia Indonesia

Rivai, Veitzal. 2010. Manajemen Sumber Daya Manusia Untuk Perusahaan. Jakarta : Raja Grafindo Persada

Sastrohadiwiryo, Siswanto. B. 2008. Manajemen Tenaga Kerja Indonesia. Jakarta : Bumi Aksara

Siagian, Sondang. P. 2012. Organisasi, Kepemimpinan dan Perilaku Administrasi. Jakarta: Gunung Agung.

Singarimbun, Masri dan Sofyan Effendi. 2009. Metode Penelitian Survey. Jakarta : LP3ES

Sutrisno, Edy. 2009. Manajemen Sumber Daya Manusia. Jakarta : Kencana

Sugiyono. 2011. Metode Penelitian Bisnis. Bandung : Alfabeta 